\title{
The erythrocyte incorporation of absorbed non-haem iron in pregnant women
}

\author{
Paul G. Whittaker*, Jon F. R. Barrett and Tom Lind \\ Department of Obstetrics and Gynaecology, University of Newcastle upon Tyne, Royal Victoria Infirmary, Newcastle, \\ Tyne and Wear NE1 4LP, UK
}

(Received 2 June 2000 - Revised 16 January 2001 - Accepted 12 March 2001)

\begin{abstract}
Studies of $\mathrm{Fe}$ absorption in pregnancy often make unfounded assumptions of erythrocyte incorporation. Therefore, we measured the absorption and utilisation of Fe during early and late pregnancy by the erythrocyte incorporation of two stable isotopes. $8.5 \mathrm{mg}{ }^{57} \mathrm{Fe}$ (oral) and $0.5 \mathrm{mg}$ ${ }^{58} \mathrm{Fe}$ (intravenous) were given to five non-pregnant women, to five women in early gestation (12 weeks) and five women in late gestation (36 weeks). The stable isotope ratios in whole blood $14 \mathrm{~d}$ later were measured by MS. Together with estimation of body Fe mass, this enabled the calculation of $\mathrm{Fe}$ absorption and erythrocyte incorporation. In non-pregnant women, $\mathrm{Fe}$ absorption averaged $20 \cdot 3$ (range $10 \cdot 2-34 \cdot 3$ ) \%. It was not significantly different in early pregnancy (11.8 (range, 4.4-24.8) \%), but during late pregnancy Fe absorption increased to 59.0 (range 38-2-77.2) \%. All non-pregnant and early-pregnancy subjects had normal Fe status, but two women in late pregnancy had evidence of Fe insufficiency. During early and late pregnancy, mean erythrocyte incorporation was 63.4 (SD 12.1) \% and 71.0 (SD 10.4)\% respectively, significantly reduced $(P=0.003)$ compared with non-pregnant subjects $(90 \cdot 1$ (SD 6.0) \%). Decreased erythrocyte incorporation of absorbed $\mathrm{Fe}$ in early pregnancy is compatible with reduced $\mathrm{Fe}$ demand and low oral absorption. However, during late pregnancy decreased erythrocyte incorporation associated with high absorption and $\mathrm{Fe}$ insufficiency is different from the high erythrocyte incorporation which occurs in non-pregnant Fe-deficient women. This suggests that part of the aetiology of Fe deficiency during pregnancy may be the reduction of $\mathrm{Fe}$ utilisation.
\end{abstract}

Iron absorption: Pregnancy: Erythrocyte: Stable isotopes: Mass spectrometry

Studies of $\mathrm{Fe}$ absorption in pregnancy have often made assumptions of erythrocyte incorporation based on nonpregnant data. The purpose of the current study was to document the changes in erythrocyte incorporation and assess the implications for the aetiology of pregnancy anaemia, since the increase in $\mathrm{Fe}$ absorption in normal pregnancy may not always prevent Fe deficiency (Barrett et al. 1994).

The incorporation of isotopes of Fe into the haemoglobin (Hb) of erythrocytes is a well-established method of measuring $\mathrm{Fe}$ absorption (Hosain et al. 1967). Oral administration of a single isotope and subsequent enrichment of isotope ratios in erythrocytes measured 2 weeks later allows semi-quantitative estimates of Fe absorption, of use mainly in comparative studies of $\mathrm{Fe}$ absorption and availability from different foods. One must assume how much of a given isotope is incorporated into erythrocytes, an incorporation which may alter from between 74 and $94 \%$ (Lunn et al. 1967) in non-pregnant individuals to $65 \%$ (Dyer \& Brill, 1972) in subjects during late pregnancy. More accurate measurements require the intravenous (iv) administration of a second isotope to account for the redistribution of the orally absorbed Fe between erythrocytes and the rest of the body and have been validated by comparison with whole-body counting using radio-isotopes (Lunn et al. 1967; Larsen \& Milman, 1975; Heinrich \& Fischer, 1982).

Most stable isotope studies have used the single isotope ${ }^{58} \mathrm{Fe}$ administered orally, and absorption has been calculated from the change in the ${ }^{58} \mathrm{Fe}:{ }^{57} \mathrm{Fe}$ ratio in erythrocytes using inductively coupled plasma MS (Fomon et al. 1988) or neutron activation analysis (Dyer \& Brill, 1972; Fairweather-Tait \& Minski, 1986). The use of oral ${ }^{54} \mathrm{Fe}$ and fast atom bombardment MS (Lehmann et al. 1988) and two oral

\footnotetext{
Abbreviations: $\mathrm{Hb}$, haemoglobin; iv, intravenous; PCV, packed cell volume.

* Corresponding author: Dr Paul G. Whittaker, present address 7905 Winston Rd, Philadelphia, PA 19118, USA, fax +1 2157537441 , email paul.whittaker@erols.com
} 
isotopes ${ }^{57} \mathrm{Fe}$ and ${ }^{58} \mathrm{Fe}$ using thermal ionisation MS has been reported (Kastenmayer et al. 1994). We have shown that administration of physiological doses of ${ }^{57} \mathrm{Fe}$ orally and ${ }^{58} \mathrm{Fe}$ iv gave reliable enrichment in erythrocytes measured by inductively coupled plasma MS (Whittaker et al. 1992) and we have applied this method to Fe absorption studies (Barrett et al. 1992). This has been followed by a dual isotope study of Fe supplementation in late pregnancy using thermal ionisation MS (O'Brien et al. 1999). We now report the clinical application of this method to both pregnant and non-pregnant subjects with due consideration of $\mathrm{Fe}$ incorporation at physiological doses.

\section{Materials and methods}

\section{Subjects}

Fifteen healthy women between the ages of 22 and 34 years volunteered for the study. Five were non-pregnant, five were between 10 and 12 weeks pregnant and five were between 36 and 37 weeks pregnant. Gestational age was calculated from the first day of the last menstrual period and confirmed by sonar measurement of fetal size. No woman had been pregnant before and no subject had a history of any medical illnesses, or if pregnant, of any obstetrical complication. None of the non-pregnant subjects were taking the oral contraceptive pill and no subject was taking vitamin or Fe supplementation. All were non-smokers. All recruits gave informed consent and the project had ethical approval from the Combined Ethics Committee of the Newcastle Regional Health Authority and Newcastle University.

\section{Study protocol}

For $3 \mathrm{~d}$ before and $2 \mathrm{~d}$ during the study each subject followed a diet plan allowing the ingestion of not more than $5 \mathrm{mg} \mathrm{Fe} / \mathrm{d}$. This was done in order to reduce variation in $\mathrm{Fe}$ intake between individuals prior to testing and to optimise isotope absorption by making the enriched isotope not an undue addition to the normal dietary intake. Following an overnight fast, the subjects attended the research unit and were seated comfortably in a warm room for $15 \mathrm{~min}$ before an iv cannula was inserted in each arm. Blood $(10 \mathrm{ml})$ was aspirated and placed in a lithium heparin tube to serve as the sample from which the basal isotope ratios would be measured. Blood was also taken sufficient to allow measurement of the woman's full blood count, serum ferritin and erythrocyte $\mathrm{Zn}$ protoporphyrin using established methods (Whittaker et al. 1996), as well as to provide serum to serve as a blank sample for use in the determination of the subject's plasma volume. The plasma volume was then measured using Evan's Blue dilution (Whittaker \& Lind, 1993) $10 \mathrm{~min}$ after injection. Erythrocyte mass (derived from plasma volume and packed cell volume (PCV)), blood volume, $\mathrm{Hb}$ mass and total $\mathrm{Fe}$ mass were calculated
(Paintin, 1963; Whittaker et al.1996):

$$
\begin{aligned}
\text { blood volume }(\mathrm{ml})= & \text { plasma volume }(\mathrm{ml}) \times(100 /(100 \\
& -(\mathrm{PCV}(\%) \times 0 \cdot 88))),
\end{aligned}
$$

total Fe mass $(\mathrm{mg})=$ blood volume $(\mathrm{l}) \times \mathrm{Hb}(\mathrm{g} / \mathrm{l})$ $\times 3.47(\mathrm{Fe}$ in $\mathrm{Hb}(\mathrm{mg} / \mathrm{g})$.

The isotopes ${ }^{57} \mathrm{Fe}$ for oral use and ${ }^{58} \mathrm{Fe}$ for iv use were prepared for administration as aqueous ferrous sulfate with added ascorbic acid ( $3 \mathrm{~g} / \mathrm{l})$ as described previously (Barrett et al. 1992). Isotopic composition of the tracers was for enriched ${ }^{57} \mathrm{Fe}(\%):{ }^{54} \mathrm{Fe} 0,{ }^{56} \mathrm{Fe} 0 \cdot 57,{ }^{57} \mathrm{Fe} 95 \cdot 93,{ }^{58} \mathrm{Fe} 3 \cdot 5$; for enriched ${ }^{58} \mathrm{Fe}(\%):{ }^{54} \mathrm{Fe} 0,{ }^{56} \mathrm{Fe} 0 \cdot 21,{ }^{57} \mathrm{Fe} 6 \cdot 56,{ }^{58} \mathrm{Fe}$ $93 \cdot 23$.

An ampoule of ${ }^{58} \mathrm{Fe}(256 \mu \mathrm{g}$ in $2 \mathrm{ml}$ with $6 \mathrm{mg}$ ascorbic acid, $\mathrm{pH}$ 1.7) was taken up into a syringe with $10 \mathrm{ml}$ normal saline and given by iv injection. After $5 \mathrm{~min}$ a $5 \mathrm{ml}$ ampoule containing $4.7 \mathrm{mg}{ }^{57} \mathrm{Fe}$ and $15 \mathrm{mg}$ ascorbic acid was emptied into a glass containing $50 \mathrm{ml}$ fresh orange juice ( $25 \mathrm{mg}$ ascorbic acid) which was drunk by the subject. This procedure is standard for administration of reference doses of Fe (Cook et al. 1991). The ampoule and glass were weighed before and after use to give the amount of isotope ingested. No food, tea or coffee were allowed for $2 \mathrm{~h}$. The following morning, again after an overnight fast, and following the same diet plan, the two isotopes were given in a similar fashion. The oral dose of ${ }^{57} \mathrm{Fe}$ was spread over $2 \mathrm{~d}$, $5 \mathrm{mg}$ being equivalent to a typical meal, and other Fe intake was reduced to $5 \mathrm{mg} / \mathrm{d}$ so that total intake remained undisturbed. Following the second test dose of Fe, subjects reverted to their normal diet. After $14 \mathrm{~d}, 10 \mathrm{ml}$ blood was taken from each subject, and the enriched $\mathrm{Fe}$ isotope ratios were measured. By $14 \mathrm{~d}$, studies have shown (Hosain et al. 1967) that tracer, absorbed and incorporated into erythrocytes, is at a stable peak.

\section{Sample preparation and analysis}

Aqueous solutions of whole blood (1:25, v/v) were prepared according to our published method (Whittaker et al. 1992). They were analysed using the inductively coupled plasma MS instrument PlasmaQuad PQ2+ (VG Elemental, Winsford, Ches., UK). Details of the operating conditions have been described and include a mass range of 51-56 Da and an analysis time of $2 \mathrm{~min} / \mathrm{sample}$ replicate, ten replicates in all. In order to obtain $\mathrm{Fe}$ isotope ratios with a precision of $<0.5 \%$, the inductively coupled plasma MS instrument had to be optimised such that ${ }^{40} \mathrm{Ar}^{16} \mathrm{O}$ was reduced to a minimum and the $\mathrm{Fe}$ concentration in the samples had to be sufficiently high to produce enough signal to be measured with the required precision without saturating the detection system. A preparation of natural Fe (atomic absorption standard; Sigma, Poole, Dorset, UK) at a concentration of $10 \mathrm{mg} / \mathrm{l}$ was used to calculate the $\mathrm{Fe}$ concentration in the samples. The mean isotope ratios of this standard were used for any bias correction of isotope ratios in the samples. The standard has no certified isotopic composition, but deviation from the internationally accepted representative isotopic composition (Commission on Atomic Weights and Isotopic Abundances, 1997), in 
practice an average value of $4 \%$ for ${ }^{57} \mathrm{Fe}:{ }^{56} \mathrm{Fe}$ and $15 \%$ for ${ }^{58} \mathrm{Fe}:{ }^{57} \mathrm{Fe}$ was used to adjust the isotope ratios of the unknown samples. Since this study was completed, a certified isotopic reference material for $\mathrm{Fe}$ has become available (IRM-014; EU Institute of Reference Materials, Geel, Belgium). Limits of detection (Miller \& Milller, 1993) were set at 3.3 SD above basal ratios for each sample, to ensure (with at least $95 \% \mathrm{CI}$ ) that changes in isotope ratios in 2-week samples were a result of isotope enrichment and not due to measurement imprecision.

\section{Calculation of $\mathrm{Fe}$ absorption}

The absorption of the oral dose of $\mathrm{Fe}$ was calculated by measuring the change in the ${ }^{57} \mathrm{Fe}:{ }^{56} \mathrm{Fe}$ ratio over the 2 -week period as well as the basal Fe mass. This was then adjusted for the redistribution of absorbed isotope by the amount of ${ }^{58} \mathrm{Fe}$ recovered 2 weeks after the iv injection and for the small amounts of ${ }^{57} \mathrm{Fe}$ present $(6.6 \%)$ in the iv preparation and of ${ }^{58} \mathrm{Fe}$ present $(3.5 \%)$ in the oral preparation. The derivation of this formula has been previously explained (Barrett et al. 1992):

$$
\begin{aligned}
& \text { total oral absorption of }{ }^{57} \mathrm{Fe} \\
& =\underset{ }{\left(\text { change in }{ }^{57} \mathrm{Fe}:{ }^{56} \mathrm{Fe}\right)}\left(\frac{\text { change in } \left.{ }^{58} \mathrm{Fe}:{ }^{56} \mathrm{Fe}\right)}{{ }^{57} \mathrm{Fe} \text { given (iv) }}\right)
\end{aligned}
$$$$
\text { and incorporation of }{ }^{58} \mathrm{Fe}
$$$$
=\frac{\text { (total circulating } \left.{ }^{56} \mathrm{Fe} \text { mass } \times \text { change in }{ }^{58} \mathrm{Fe}:{ }^{56} \mathrm{Fe}\right)}{\text { Fe given }(\text { iv) }} \text {. }
$$

\section{Statistics}

Results are given as mean values and standard deviations or geometric mean values (range) for Fe absorption and serum ferritin. Statistical comparison of groups was by one-way ANOVA with multiple comparisons controlled using the Student-Newman-Keuls method (SigmaStat for Windows; SPSS Science, Chicago, IL, USA). Associations were assessed by linear regression. The significance level (twosided) was $P<0 \cdot 05$

\section{Results}

Isotope ratios, measurement precision and results of $\mathrm{Fe}$ absorption and incorporation are shown in Table 1. The mean basal ${ }^{57} \mathrm{Fe}:{ }^{56} \mathrm{Fe}$ and ${ }^{58} \mathrm{Fe}:{ }^{56} \mathrm{Fe}$ ratios and their measurement precision were not significantly different between groups (Table 1). The average precision of the ${ }^{57} \mathrm{Fe}:{ }^{56} \mathrm{Fe}$ ratios $(0.25 \%)$ was equivalent to a minimal detectable absorption of $3 \%$. Clinical details and indices of Fe status are given in Table 2.

\section{Non-pregnant subjects}

The measured absorption ranged from 10 to $34 \%$ (geometric mean value $20 \%$ ). Using the Fe mass derived from the dye-dilution technique the percentage of the iv dose that was incorporated into the erythrocytes ranged from 83 to $97 \%$ (mean value $90 \%$ ). All subjects had $\mathrm{Hb}$ and PCV concentrations within normal limits (Centers for Disease Control, 1989). The subject with the highest ferritin $(89 \mu \mathrm{g} / \mathrm{l})$ had the lowest absorption $(10 \cdot 2 \%)$, while the subject with a low ferritin concentration suggestive of storage Fe depletion (7 ug/l) had an absorption of $24.9 \%$, above the mean value.

\section{Pregnant subjects}

The mean increase in the ${ }^{58} \mathrm{Fe}:{ }^{56} \mathrm{Fe}$ ratio in response to the iv doses did not differ between early and late pregnancy

Table 1. Erythrocyte iron isotopic enrichment and iron absorption during pregnancy*

\begin{tabular}{|c|c|c|c|c|c|c|}
\hline & \multicolumn{2}{|c|}{ Non-pregnant } & \multicolumn{2}{|c|}{12 weeks gestation } & \multicolumn{2}{|c|}{36 weeks gestation } \\
\hline & Mean & SD & Mean & SD & Mean & SD \\
\hline $\begin{array}{l}\text { Basal }{ }^{57} \mathrm{Fe}:{ }^{56} \mathrm{Fe} \\
\quad \mathrm{SD} \text { (within subjects) }\end{array}$ & $\begin{array}{l}0.02395 \\
0.00005\end{array}$ & 0.00009 & $\begin{array}{l}0.02385 \\
0.00007\end{array}$ & 0.00017 & $\begin{array}{l}0.02386 \\
0.00005\end{array}$ & 0.00006 \\
\hline Precision ${ }^{57} \mathrm{Fe}:{ }^{56} \mathrm{Fe}(\%)$ & 0.22 & 0.07 & 0.28 & 0.14 & 0.19 & 0.06 \\
\hline Detection limit (3.3 SD) & 0.02411 & & 0.02405 & & 0.02400 & \\
\hline${ }^{57} \mathrm{Fe}:{ }^{56} \mathrm{Fe}$ at 2 weeks & 0.02511 & 0.00057 & 0.02443 & 0.00043 & 0.02594 & 0.00069 \\
\hline SD (within subjects) & 0.00005 & & 0.00008 & & 0.00007 & \\
\hline Precision ${ }^{57} \mathrm{Fe}:{ }^{56} \mathrm{Fe}(\%)$ & 0.20 & 0.08 & 0.33 & 0.12 & 0.28 & 0.09 \\
\hline Ratio increase & 0.00116 & 0.00052 & 0.00058 & 0.00041 & 0.00208 & 0.00069 \\
\hline Increase (SD multiple) & $23 \cdot 4$ & & $9 \cdot 1$ & & $46 \cdot 1$ & \\
\hline Basal ${ }^{58} \mathrm{Fe}:{ }^{56} \mathrm{Fe}$ & 0.00295 & 0.00005 & 0.00301 & 0.00001 & 0.00302 & 0.00002 \\
\hline SD (within subjects) & 0.00001 & & 0.00001 & & 0.00001 & \\
\hline Precision ${ }^{58} \mathrm{Fe}:{ }^{56} \mathrm{Fe}(\%)$ & 0.47 & 0.12 & 0.45 & 0.21 & 0.34 & 0.07 \\
\hline Detection limit (3.3 SD) & 0.00299 & & 0.00305 & & 0.00305 & \\
\hline${ }^{58} \mathrm{Fe}:{ }^{56} \mathrm{Fe}$ at 2 weeks & 0.00330 & 0.00006 & 0.00328 & 0.00004 & 0.00330 & 0.00005 \\
\hline SD (within subjects) & 0.00002 & & 0.00001 & & 0.00001 & \\
\hline Precision ${ }^{58} \mathrm{Fe}:{ }^{56} \mathrm{Fe}(\%)$ & 0.48 & 0.16 & 0.42 & 0.17 & 0.34 & 0.20 \\
\hline Ratio increase & 0.00035 & 0.00004 & 0.00027 & 0.00004 & 0.00028 & 0.00006 \\
\hline Increase (SD multiple) & $27 \cdot 2$ & & $25 \cdot 3$ & & $27 \cdot 8$ & \\
\hline
\end{tabular}
(Mean values and standard deviations for five subjects with ten replicate measurements on each occasion)

* For details of subjects and procedures, see p. 324. Enrichments were measured 2 weeks after isotope administration. 
Table 2. Oral iron absorption and iron status during pregnancy ${ }^{\star}$ (Mean values and standard deviations for five subjects)

\begin{tabular}{|c|c|c|c|c|c|c|}
\hline & \multicolumn{2}{|c|}{ Non-pregnant } & \multicolumn{2}{|c|}{12 weeks gestation } & \multicolumn{2}{|c|}{36 weeks gestation } \\
\hline & Mean & SD & Mean & SD & Mean & SD \\
\hline Height (m) & 1.63 & 0.04 & 1.66 & 0.03 & 1.64 & 0.06 \\
\hline Weight (kg) & $57 \cdot 4$ & $2 \cdot 8$ & $63 \cdot 2$ & 11.4 & $74 \cdot 3^{\star}$ & $9 \cdot 4$ \\
\hline $\mathrm{Hb}(\mathrm{g} / \mathrm{l})$ & 138 & 6 & $123 \dagger \dagger$ & 6 & $120 \dagger \dagger$ & 12 \\
\hline Packed cell volume (I/l) & 0.404 & 0.021 & $0.358+\dagger$ & 0.019 & $0.357+\dagger$ & 0.027 \\
\hline Ferritin $(\mu \mathrm{g} / \mathrm{l})$ & 33.8 & $7 \cdot 0-89.0 \dagger$ & $26 \cdot 7$ & $10 \cdot 0-86 \cdot 0 \dagger$ & $12 \cdot 3$ & $5 \cdot 0-89 \cdot 0 \dagger$ \\
\hline Mean cell volume (fl) & 87.9 & 4.5 & $89 \cdot 8$ & 2.9 & $87 \cdot 2$ & 3.4 \\
\hline $\mathrm{ZPP}(\mu \mathrm{g} / \mathrm{g} \mathrm{Hb})$ & 1.9 & 0.2 & 1.6 & 0.4 & $2 \cdot 6^{\star \star}$ & 0.6 \\
\hline Blood volume $(\mathrm{ml} / \mathrm{kg})$ & $64 \cdot 4$ & $3 \cdot 4$ & $64 \cdot 4$ & $8 \cdot 4$ & 72.9 & $5 \cdot 6$ \\
\hline $\mathrm{Hb}$ mass $(\mathrm{g})$ & 508 & 43 & 494 & 45 & $650^{\star *}$ & 107 \\
\hline Oral dose ${ }^{57} \mathrm{Fe}(\mathrm{mg})$ & 8.48 & 0.41 & 8.23 & 0.27 & 8.90 & 0.09 \\
\hline Dose ${ }^{58} \mathrm{Fe}$ iv $(\mathrm{mg})$ & 0.52 & 0.01 & 0.52 & 0.01 & 0.51 & 0.01 \\
\hline${ }^{57} \mathrm{Fe}$ oral absorption (\%) & $20 \cdot 3$ & $10 \cdot 2-34 \cdot 3 \dagger$ & $11 \cdot 8$ & $4.4-24.8 \dagger$ & $59 \cdot 0^{\star \star}$ & $38 \cdot 2-77 \cdot 2 \dagger$ \\
\hline${ }^{58} \mathrm{Fe}$ iv recovery $(\%)$ & $90 \cdot 1$ & $6 \cdot 0$ & $63.4+t$ & $12 \cdot 4$ & $71.0+\dagger$ & $10 . \overline{6}$ \\
\hline
\end{tabular}

$\mathrm{Hb}$, haemoglobin, ZPP, zinc protoporphyrin; iv, intravenous.

${ }^{*}$ For details of subjects and procedures, see p. 324.

† Geometric mean value (range).

Mean values were significantly different from those in preceding columns (ANOVA): ${ }^{* *} P<0.01$.

Mean values were significantly different from those of the non-pregnant group (ANOVA): †† $P<0.01$

and the non-pregnant subjects. The mean increase in the ${ }^{57} \mathrm{Fe}:{ }^{56} \mathrm{Fe}$ ratio and the calculated oral $\mathrm{Fe}$ absorption was significantly higher $(P=0.002)$ in the subjects in late pregnancy (range 38-77\%) compared with those in early pregnancy (range $4-25 \%$ ) and to those who were not pregnant. At 12 weeks gestation, the lower enrichment of the erythrocyte ${ }^{57} \mathrm{Fe}:{ }^{56} \mathrm{Fe}$ ratio and the calculated absorption did not reach statistical significance when compared with the non-pregnant subjects. The percentage of the iv dose that was incorporated into the erythrocytes at 12 and 36 weeks gestation ranged from 47 to $78 \%$ and 62 to $88 \%$ respectively, both being significantly lower $(P=0.003)$ than the recovery measured in the non-pregnant subjects.

The average blood volume $(\mathrm{ml})$ and $\mathrm{Hb}$ mass were not different between non-pregnant subjects and those subjects studied during early pregnancy, but in the subjects studied during late pregnancy total blood volume was greater on average by $35 \%$ (3995 (SD 211) v. 5384 (SD 518) $\mathrm{ml}, P<0.001)$ and $\mathrm{Hb}$ mass $(\mathrm{g})$ by $32 \%(P=$ $0 \cdot 008$, Table 2). Body weight was $18 \%$ greater in the late pregnancy compared with the early pregnancy group, proportionately less than the rise in $\mathrm{Hb}$ mass. Individual measurements of blood volume expressed per unit weight varied from 54 to $81 \mathrm{ml} / \mathrm{kg}$, but the wide variation meant that comparison of the three group means was not significant $(P=0 \cdot 075)$. Examination of individual results showed that a reduction of $10 \mathrm{ml} / \mathrm{kg}$ in blood volume (e.g. using a calculated blood volume of $60 \mathrm{ml} / \mathrm{kg}$ instead of an assumed blood volume of $70 \mathrm{ml} / \mathrm{kg}$ ) would reduce the estimate of $\mathrm{Fe}$ incorporation by $12 \%$ (i.e. from 75 to $63 \%)$.

An inverse relationship was found between oral $\mathrm{Fe}$ absorption and the concentration of serum ferritin. Taking all fifteen subjects together, the correlation of ferritin with $\mathrm{Fe}$ absorption was significant $\left(r^{2} 0 \cdot 483, P=0.004\right.$, using a logarithmic function) while erythrocyte incorporation showed no significant association with ferritin $\left(r^{2} 0 \cdot 06\right)$.
Furthermore, at 36 weeks the two subjects with the highest oral absorption (77.2 and $70.0 \%)$ and reduced erythrocyte incorporation (68 and $73 \%$ ) had evidence of $\mathrm{Fe}$ insufficiency. (This was defined as a fall in mean cell volume from early pregnancy of more than $6 \mathrm{fl}$ or a rise in $\mathrm{Zn}$ protoporphyrin above the normal range of $3 \mu \mathrm{g} / \mathrm{g} \mathrm{Hb}$, in the presence of $\mathrm{Hb}$ at or above $110 \mathrm{~g} / \mathrm{l}$ (Barrett et al. 1994).) One subject had a $\mathrm{Hb}$ value of $110 \mathrm{~g} / \mathrm{l}$, serum ferritin $7 \mu \mathrm{g} / \mathrm{l}$, $\mathrm{Zn}$ protoporphyrin $2.5 \mu \mathrm{g} / \mathrm{g} \mathrm{Hb}$ and a fall in mean cell volume of $7.4 \mathrm{fl}$ since 12 weeks gestation, while the other subject with a $\mathrm{Hb}$ of $111 \mathrm{~g} / \mathrm{l}$ and serum ferritin $5 \mu \mathrm{g} / \mathrm{l} \mathrm{had} \mathrm{a}$ Zn protoporphyrin of $3.6 \mu \mathrm{g} / \mathrm{g} \mathrm{Hb}$ and a fall in mean cell volume of $5 \mathrm{fl}$ (within the normal range (Whittaker et al. 1996)).

\section{Discussion}

The use of the dual-isotope technique eliminates the errors that assumptions of erythrocyte incorporation may have on the calculation of $\mathrm{Fe}$ absorption. In order to quantify incorporation, some calculation of the total Fe mass was needed. This was achieved by a measurement of plasma volume and calculation of blood volume. In pregnancy, this measurement for individuals may differ substantially from literature-based estimates, such as blood volume being $70 \mathrm{ml} / \mathrm{kg}$ (Fomon et al. 1988; O'Brien et al. 1999) and can be derived for individual subjects from the equations we provide (see Appendix) using height as well as weight. Furthermore, the use of an individually determined figure for $\mathrm{Fe}$ incorporation, such as $60 \%$, instead of an assumed figure of $90 \%$, would mean that daily utilisation of Fe intake would be reduced by a third.

Whole-body counting has established that normal, nonpregnant, non-anaemic women, given $5 \mathrm{mg} \mathrm{Fe}$ whilst fasted, will absorb between 10 and $20 \%$ of the administered dose (Heinrich, 1970; Bothwell et al. 1979). Some of our subjects had results slightly higher than this, which could be 
explained by natural variability, the positive effect of ascorbic acid or by the low-Fe diet for the days preceding and during the test. In addition, one non-pregnant subject with high absorption was Fe depleted (serum ferritin $<12 \mu \mathrm{g} / \mathrm{l}$ ) (Bothwell et al. 1979).

We found the average absorption in early pregnancy of $11.8 \%$ comparable with other studies which have measured the absorption of aqueous Fe during pregnancy (Whittaker et al. 1991) and our average of $59 \%$ absorption for late pregnancy demonstrated once again the increase in $\mathrm{Fe}$ absorption during pregnancy. Other investigators using aqueous $\mathrm{Fe}$ in late pregnancy have reported $38 \%$ absorption (dose 2-9 mg; Hahn et al. 1951), 51\% (dose 4-7 mg; Dyer \& Brill, 1972) and $37 \%$ (dose 5 mg; Whittaker et al. 1991). Studies showing low absorption in late pregnancy have used supra-physiological doses (giving $14 \%$ absorption from $100 \mathrm{mg}$; Svanberg et al. $1975 \mathrm{~b}$ ) or used Fe in meals of low bioavailability (Svanberg et al. 1975a). Our data also suggested that absorption in early pregnancy was slightly lower than in the non-pregnant subjects, though the wide range of absorption did not support statistical significance. Nevertheless, this relationship has been suggested in other studies (Svanberg, 1975) and makes teleological sense as the $\mathrm{Fe}$ demand in early pregnancy is less than in nonpregnancy since menstruation is avoided (Bothwell et al. 1979). Pregnancy may also influence the ferrokinetics of absorbed Fe. In early pregnancy, non-pregnant or lower levels of absorption were accompanied by reduced levels of $\mathrm{Fe}$ incorporation into erythrocytes. While some suggest erythropoiesis is increased early in pregnancy (Howells et al. 1986), others have shown evidence for reduced erythropoiesis (Beguin et al. 1991) and the absorbed Fe may remain extramedullary, or if transferred to the marrow, not incorporated into new erythrocytes. The high demand, high absorption of late pregnancy might be associated with apparent low erythrocyte incorporation of $\mathrm{Fe}$, as some of the absorbed $\mathrm{Fe}$ will be transferred to the fetus and not deposited in the marrow. The Fe demand of fetus and placenta in late pregnancy is estimated to be of a similar amount to the demands of the increased erythrocyte mass in mid pregnancy (Barrett et al. 1994) although both the amount and variation in fetal demand is difficult to quantify in individuals. The lower level of erythrocyte incorporation of $\mathrm{Fe}$ in late pregnancy also indicates that the ferrokinetics of late pregnancy are different from that which occurs in anaemic non-pregnant patients in whom high erythrocyte incorporation of $\mathrm{Fe}$ is usually found (Finch, 1970). The physiological mechanisms for our hypothesis remain uncertain, though competition for Fe utilisation or changes in Fe transport or receptor binding are possible.

Only two other studies have applied the principles of dual isotopic erythrocyte incorporation to stable isotopes. Dyer $\&$ Brill (1972) measured the Fe absorption in a group of twelve pregnant women between 23 and 38 weeks gestation using ${ }^{58} \mathrm{Fe}$ and neutron activation analysis. The single $\mathrm{Fe}$ isotope was used sequentially both as an indicator of erythrocyte incorporation (iv dose) and absorption (oral dose). They also used ${ }^{50} \mathrm{Cr}$ to measure plasma volumes of the subjects. Their measurement of absorption in late pregnancy agrees with ours, as does their measured erythrocyte incorporation at 64.7 (SD 12.2) \%, similar to our measured levels of 63.4 and $71.0 \%$ in early and late pregnancy respectively. This erythrocyte incorporation was significantly lower than in our non-pregnant subjects, an average of $90 \cdot 2 \%$. This suggests that an assumed value for erythrocyte incorporation might not apply to pregnant subjects, and may lead to an overestimation of Fe utilisation by single isotope studies during pregnancy.

A recent dual-isotope study of Peruvian women in late pregnancy (O'Brien et al. 1999) found that unsupplemented women absorbed only an average of $12 \%$ of a $10 \mathrm{mg} \mathrm{Fe}$ dose while Fe-supplemented women absorbed $10 \%$ of a $60 \mathrm{mg}$ dose. The response of the control women is suprising since it suggests no dose-response relationship, unlike other studies (Bothwell et al. 1979), and no pregnancy effect of the level we and others have found. One explanation may be that the bioavailability of the test solution was low (stored and administered without ascorbic acid) and further comparison against a reference dose and a non-pregnant control group is warranted. Fe incorporation data in this study were limited by the use of a standard blood volume formula that ignores individual variability (as noted earlier). However, the data suggest that erythrocyte incorporation was higher (and highly variable) in the control group (92 (SD $28) \%$ ) than in the supplemented groups (75 (SD 15)\%). This may be part of the reason for their finding that the $\mathrm{Hb}$ and PCV did not differ between control and supplemented groups after an average of 17 weeks of supplementation at $60 \mathrm{mg} / \mathrm{d}$, and had not in fact risen in the supplemented groups since the start of therapy (though ferritin was significantly raised). It would also be valuable to assess whether the response to supplementation was inversely related to the $\mathrm{Hb}$ status of the fetus and neonate and whether more Fe-deficient women transferred more Fe to the fetus.

In the current study and others (Barrett et al. 1994; O'Brien et al. 1999), the concentration of serum ferritin was inversely related to Fe absorption during pregnancy, and the two pregnant subjects in late pregnancy with evidence of $\mathrm{Fe}$ insufficiency had the highest absorption. However, the finding (Barrett et al. 1994) that Fe absorption doubled between 24 and 36 weeks of pregnancy while ferritin and $\mathrm{Hb}$ remained unchanged suggests that other factors (such as fetal demand) also drive Fe absorption up in late pregnancy. The post-absorptive serum method, which reflects the amount of Fe immediately absorbed into the body, found the amount of $\mathrm{Fe}$ absorbed at 36 weeks was not different in anaemic $v$. non-anaemic subjects (Barrett et al. 1994). As the erythrocyte incorporation method reflects also the $\mathrm{Fe}$ that is used by the marrow to synthesise $\mathrm{Hb}$, the erythrocyte method is more likely to correlate estimates of absorption with marrow Fe stores and erythropoiesis. We suggest that anaemia developing during pregnancy may be the result of alterations in the fate of absorbed $\mathrm{Fe}$, rather than just a result of poor absorption. It is possible that by applying both the post-absorptive serum method and the erythrocyte incorporation method concurrently to pregnant anaemic women, a difference in absorption results would reflect the reduced ability of that subject to incorporate absorbed $\mathrm{Fe}$ into $\mathrm{Hb}$. Longitudinal studies of erythrocyte incorporation may help to identify the process by which Fe-deficiency anaemia develops in the presence of good dietary intake and increased oral absorption. 


\section{Acknowledgements}

We are grateful to John Williams (NERC ICP-MS unit) for technical assistance. The study was supported by grants from the Medical Research Council, Action Research for the Crippled Child and the Royal Society.

\section{References}

Barrett JFR, Whittaker PG, Williams JG \& Lind T (1992) Absorption of non-haem iron in normal women measured by incorporation of two stable isotopes into erythrocytes. Clinical Science 83, 213-219.

Barrett JFR, Whittaker PG, Williams JG \& Lind T (1994) Absorption of non-haem iron from food during normal pregnancy. British Medical Journal 309, 79-82.

Beguin Y, Lipscei G, Thoumsin H \& Fillet G (1991) Blunted erythropoietin production and decreased erythropoiesis in early pregnancy. Blood 78, 89-93.

Bothwell TH, Charlton RW, Cook JD \& Finch CA (1979) Iron Metabolism in Man. Oxford: Blackwell.

Centers for Disease Control (1989) Criteria for anemia in children and childbearing-aged women. Morbidity and Mortality Weekly Report 38, 400-404.

Commission on Atomic Weights and Isotopic Abundances (1997) Isotopic composition of the elements 1997. http://www.physics. curtin.edu.au/IUPAC/Final97.doc

Cook JD, Dassenko SA \& Lynch SR (1991) Assessment of the role of nonheme-iron availability in iron balance. American Journal of Clinical Nutrition 54, 717-722.

Documenta Geigy (1981) Scientific Tables, 8th ed. Basle: CibaGeigy.

Dyer NC \& Brill AB (1972) Use of the stable tracers 58-Fe and $50-\mathrm{Cr}$ for the study of iron utilization in pregnant women. In Nuclear Activation in the Life Sciences, pp. 469-477 [Anonymous, editor]. Vienna: IAEA.

Fairweather-Tait SJ \& Minski MJ (1986) Studies on iron availability in man, using stable isotope techniques. British Journal of Nutrition 55, 279-285.

Finch CA (1970) Ferrokinetics in man. Medicine 49, 17-53.

Fomon SJ, Janghorbani M, Ting BTG, Ziegler EE, Rogers RR, Nelson SE, Ostedgaard LS \& Edwards BB (1988) Erythrocyte incorporation of ingested 58-iron by infants. Pediatric Research 24, 20-24.

Hahn PF, Carothers EL, Darby WJ, Martin M, Sheppard CW \& Cannon RO (1951) Iron metabolism in early pregnancy as studied with the radioactive isotope Fe59. American Journal of Obstetrics and Gynecology 61, 477-486.

Heinrich HC (1970) Intestinal iron absorption in man - methods of measurement, dose relationships, diagnostic and therapeutic applications. In Iron Deficiency. Pathogenesis. Clinical Aspects. Therapy, pp. 213-296 [L Hallberg, HG Harwerth and A Vannoti, editors]. London: Academic Press.

Heinrich HC \& Fischer R (1982) Correlation of post-absorptive serum iron increase and erythrocyte 59-Fe incorporation with the whole body retention of absorbed 59-Fe. Klinische Wochenschrift 60, 1493-1496.

Hosain F, Marsaglia G \& Finch CA (1967) Blood ferrokinetics in normal man. Journal of Clinical Investigation 46, 1-9.

Howells MR, Jones SE, Napier JA, Saunders K \& Cavill I (1986) Erythropoiesis in pregnancy. British Journal of Haematology 64, 595-599.

Kastenmayer P, Davidsson L, Galan P, Cherouvrier F, Hercberg S \& Hurrell RF (1994) A double stable isotope technique for measuring iron absorption in infants. British Journal of Nutrition 71, 411-424.
Larsen L \& Milman N (1975) Normal iron absorption determined by means of whole body counting and red cell incorporation of 59Fe. Acta Medica Scandinavica 198, 271-274.

Lehmann WD, Fischer R \& Heinrich HC (1988) Iron absorption in man calculated from erythrocyte incorporation of the stable isotope iron-54 determined by fast atom bombardment mass spectrometry. Analytical Biochemistry 172, 151-159.

Lunn JA, Richmond J, Simpson JD, Leask JD \& Tothill P (1967) Comparison of three radioactive methods of measuring iron absorption. British Medical Journal 3, 331-333.

Miller JC \& Miller JM (1993) Statistics for Analytical Chemistry, 3rd ed., pp. 115-116. Chichester: Ellis Harwood Ltd.

O'Brien KO, Zavaletta N, Caulfield LE, Yang DX \& Abrams SA (1999) Influence of prenatal iron and zinc supplements on supplemental iron absorption, red blood cell iron incorporation, and iron status in pregnant Peruvian women. American Journal of Clinical Nutrition 69, 509-515.

Paintin DB (1963) The haematocrit ratio in pregnancy. Journal of Obstetrics and Gynaecology of the British Commonwealth 70, 807-810.

Svanberg B (1975) Iron absorption in early pregnancy - a study of the absorption of non-haeme iron and ferrous iron in early pregnancy. Acta Obstetricia Gynecologica Scandinavica 48, Suppl., 69-86.

Svanberg B, Arvidsson B, Bjorn-Rasmussen E, Hallberg L, Rossander L \& Swolin B (1975a) Dietary iron absorption in pregnancy - a longitudinal study with repeated measurements of non-haeme iron absorption from the whole diet. Acta Obstetricia Gynecologica Scandinavica 48, Suppl., 43-86.

Svanberg B, Arvidsson B, Norrby A, Rybo G \& Solvell L (1975b) Absorption of supplemental iron during pregnancy - a longitudinal study with repeated bone-marrow studies and absorption measurements. Acta Obstetricia Gynecologica Scandinavica 48, Suppl., 87-108.

Whittaker PG, Barrett JFR \& Williams JG (1992) Precise determination of iron isotope ratios in whole blood using ICPMS. Journal of Analytical Atomic Spectrometry 7, 109-113.

Whittaker PG \& Lind T (1993) The intravascular mass of albumin during human pregnancy. British Journal of Obstetrics and Gynaecology 100, 587-592.

Whittaker PG, Lind T \& Williams JG (1991) Iron absorption during normal human pregnancy: a study using stable isotopes. British Journal of Nutrition 65, 457-463.

Whittaker PG, MacPhail S \& Lind T (1996) Serial hematologic changes and pregnancy outcome. Obstetrics and Gynecology $\mathbf{8 8}$, $33-39$.

\section{APPENDIX}

\section{Calculation of plasma volume and blood volume}

We present here, for the benefit of future investigators, Tables enabling calculation of plasma volume in relation to maternal height, weight and haemoglobin. Estimates of plasma volume were derived in a serial study using Evans Blue dye dilution on fifty-six women (without $\mathrm{Fe}$ supplementation) and the data on changes in the mean values of plasma volume and haematology have been published (Whittaker \& Lind, 1993; Whittaker et al. 1996). Regression analysis showed height and haemoglobin were significant variables as well as weight. Comparison of our equation in Table A2 for non-pregnant women with that published in a reference text (Documenta Geigy, 1981) gave a mean difference between estimates of 204 (SD 72) ml ( $n$ 64). We also show the changes in blood volume in our subjects expressed in terms of body weight. 
Table A1. Estimation of plasma volume during pregnancy from maternal height, weight and haemoglobin*

\begin{tabular}{|c|c|c|c|c|c|c|c|c|}
\hline & \multirow[b]{2}{*}{ Non-pregnant } & \multicolumn{6}{|c|}{ Time from last menstrual period (weeks) } & \multirow[b]{2}{*}{12 weeks post-natal } \\
\hline & & 7 & 12 & 20 & 28 & 36 & 38 & \\
\hline B1 & $18 \cdot 9$ & $18 \cdot 3$ & $24 \cdot 6$ & $25 \cdot 2$ & $27 \cdot 7$ & $29 \cdot 3$ & $24 \cdot 2$ & $27 \cdot 6$ \\
\hline B2 & 14.9 & $-1 \cdot 3$ & 8.6 & 9.8 & $10 \cdot 2$ & $13 \cdot 6$ & $12 \cdot 4$ & $7 \cdot 6$ \\
\hline B3 & -82.0 & -145 & -125 & -185 & -186 & -247 & $-68 \cdot 8$ & -95.4 \\
\hline A & -482 & +1412 & -312 & +532 & +378 & +605 & -463 & -1313 \\
\hline $\mathrm{R}$ & 0.710 & 0.502 & 0.586 & 0.667 & 0.610 & 0.659 & 0.402 & 0.664 \\
\hline PV (mean value, $\mathrm{ml}$ ) & 2378 & 2472 & 2667 & 3108 & 3541 & 3646 & 3620 & 2409 \\
\hline CV of estimate (\%) & 8.9 & $10 \cdot 6$ & $9 \cdot 2$ & 8.1 & $9 \cdot 1$ & $10 \cdot 4$ & $12 \cdot 3$ & $9 \cdot 1$ \\
\hline
\end{tabular}

$\mathrm{PV}$, plasma volume.

${ }^{*} \mathrm{PV}^{(\mathrm{ml})}=(\mathrm{Ht}(\mathrm{cm}) \times \mathrm{B} 1)+(\mathrm{Wt}(\mathrm{kg}) \times \mathrm{B} 2)+(\mathrm{Hb}(\mathrm{g} / \mathrm{dl}) \times \mathrm{B} 3)+\mathrm{A}$, where $\mathrm{Ht}$ is the height and $\mathrm{Hb}$ is the haemoglobin.

Table A2. Estimation of plasma volume during pregnancy from maternal height and weight if haemoglobin data are unavailable or iron supplementation is given*

\begin{tabular}{|c|c|c|c|c|c|c|c|c|}
\hline & \multirow[b]{2}{*}{ Non-pregnant } & \multicolumn{6}{|c|}{ Time from last menstrual period (weeks) } & \multirow{2}{*}{$\begin{array}{l}12 \text { weeks } \\
\text { post-natal }\end{array}$} \\
\hline & & 7 & 12 & 20 & 28 & 36 & 38 & \\
\hline B1 & $20 \cdot 2$ & $21 \cdot 8$ & $24 \cdot 2$ & $27 \cdot 9$ & $25 \cdot 6$ & $36 \cdot 1$ & $22 \cdot 9$ & $28 \cdot 3$ \\
\hline B2 & 14.9 & -4.7 & 5.9 & 1.7 & 5.8 & 11.0 & $11 \cdot 8$ & $6 \cdot 8$ \\
\hline A & -1793 & -815 & -1648 & -1557 & -1040 & -3029 & -982 & -2637 \\
\hline $\mathrm{R}$ & 0.676 & 0.354 & 0.490 & 0.455 & 0.392 & 0.478 & 0.382 & 0.598 \\
\hline CV of estimate (\%) & $9 \cdot 3$ & $11 \cdot 3$ & $9 \cdot 7$ & $9 \cdot 6$ & $10 \cdot 5$ & $12 \cdot 0$ & $12 \cdot 2$ & 9.5 \\
\hline
\end{tabular}

${ }^{*} \mathrm{PV}(\mathrm{ml})=(\mathrm{Ht}(\mathrm{cm}) \times \mathrm{B} 1)+(\mathrm{Wt}(\mathrm{kg}) \times \mathrm{B} 2)+\mathrm{A}$, where $\mathrm{PV}$ is the plasma volume and $\mathrm{Ht}$ is the height.

Table A3. Blood volume during pregnancy expressed per body weight $(\mathrm{ml} / \mathrm{kg})$

\begin{tabular}{|c|c|c|c|c|c|c|c|c|}
\hline & \multirow[b]{2}{*}{ Non-pregnant } & \multicolumn{6}{|c|}{ Time from last menstrual period (weeks) } & \multirow[b]{2}{*}{12 weeks post-natal } \\
\hline & & 7 & 12 & 20 & 28 & 36 & 38 & \\
\hline Mean & $62 \cdot 7$ & $63 \cdot 2$ & 65.4 & $70 \cdot 8$ & 73.5 & $72 \cdot 3$ & 71.4 & $61 \cdot 2$ \\
\hline SD & $6 \cdot 4$ & 9.5 & 8.0 & 8.0 & 8.5 & 8.6 & $8 \cdot 7$ & 6.9 \\
\hline Minimum & $50 \cdot 2$ & 44.6 & $49 \cdot 7$ & $55 \cdot 1$ & $56 \cdot 7$ & 55.5 & $54 \cdot 3$ & $47 \cdot 6$ \\
\hline Maximum & $75 \cdot 3$ & $81 \cdot 7$ & $81 \cdot 1$ & 86.5 & $90 \cdot 2$ & $89 \cdot 1$ & 88.6 & 74.8 \\
\hline$n$ & 50 & 52 & 56 & 53 & 52 & 51 & 45 & 56 \\
\hline
\end{tabular}

